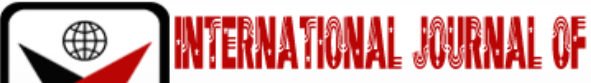

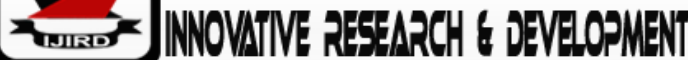

ISSN 2278-0211 (Online)

\section{Cultural Tourism Potentials of Dayi Traditional Pottery Art}

\author{
Nyamawero Navei \\ Tutor, Department of Home Economics, \\ Tumu Senior High Technical School, Ghana
}

\begin{abstract}
:
Dayi is one of the leading traditional pottery production hubsin Sissala East Municipality in the Upper West Region of northern Ghana. Traditional pottery wares of various types, decorative designs, cultural semiotics and relevance are produced in Dayi. However, the cultural tourism potentials of these handiworks seemingly remain unexamined. The study therefore took a qualitative descriptive path in examining selected traditional pottery wares produced in Dayi to reveal their cultural tourism potentials. Twenty (20) purposively sampled respondents were contacted with data collected through unstructured interviews, field observation and photography. The study finds the pottery receptacles produced in Dayi as repositories of indigenous cultural heritage, artistry, philosophy, knowledge and skills of the people of Dani. Besides, the indigenous decorative designs and the premises of the deployment of pottery receptacles in Dayi are underpinned by the sociocultural, socioreligious, sociopolitical and socioeconomic lifelines of the rural Dayi people positing sufficient grounds and the need for the development of Dayi traditional pottery art into an attractive cultural tourism destination for global patronage.Therefore, it is recommended that the key stakeholders (Chief, Queen Mother and Elders of Dani; Assembly Member of the Area; Municipal Chief Executive of Sissala East Municipal Assembly, the Regional Management of Ghana Tourism Authority, and the Municipal Directorate of Centre for National Culture) should collaborate to ensure that a quick reconnaissance survey of Dayi traditional pottery art is conducted by the regional management of Ghana Tourism Authority. This would give birth to appropriate interventions required for the development of an attractive cultural tourism destination in Dani and the promotion of Dayi traditional pottery wares on Ghana Tourism Authority's Single Window Destination online portal for global patronage and economic empowerment of the rural potters in Dani.
\end{abstract}

Keywords: Cultural tourism, Dani traditional pottery art, potentials, pottery wares/receptacles, Sissala East Municipality

\section{Introduction}

Dani, corrupted as Dane or Dangi, is a Sisaala (Sissala) community located in the Sissala East Municipality in the Upper West Region of northern Ghana. The people of Dani belong to the Hanvia clan which consists of communities such as; Sakai, Nankpawie, Kong, Dani, Lilixia, Bichembelle, Gwosi, Santijan and Funsi all found in the Sissala enclave. Hanvia is a clan that encapsulates Sisaala people of the same ancestral lineage who revere the earthen bowl as their totem. Dani is about 7.6 Kilometres and 12-13 minutes' drive/ride from Tumu, the capital town of the Sissala East Municipal (Google Map, 2021). Geographically, Dani is situated between Kong and Nankpawie but 2 kilometers extreme west of the Tumu Bugubele - Wellembele to Wa main road. Farming is the major occupation of the indigenes of Dani. Besides farming, the people of Dani resort to traditional arts such as; pottery, basketry, carving, blacksmithing, spinning and hand weaving of cotton into fabrics for fashioning into smocks and other garments. Although some of the aforementioned traditional arts are in the decline, pottery art is one area that has over the years received the needed attention by the rural women of Dani. This makes Dani one of the leading traditional pottery production hubs in the Sissala East Municipality. In this era of globalisation and its associated negative impacts on African indigenous arts, the rural women of Dani are still engrossed in the production of traditional pottery wares of various types, decorative designs, cultural semiotics and relevanceto meet their sociocultural, socioreligious, sociopolitical needs while making economic gains from the art through the sale of some of the receptacles to other communities within the Upper West Region and Ghana at large. Although, similar traditional pottery centres in Ghana such as Sirigu traditional pottery and art has metamorphosed into a well-reputed global tourism and research destination in the Kassena-Nankana West District in the Upper East Region of northern Ghana (Wemegah, 2009; Asmah, Mate \&Daitey, 2016; Sheldon, 2016; Yussif\& Adu-Gyamfi, 2017, Yussif, Adu-Gyamfi \& Tabi-Agyei, 2018), the cultural tourism potentials of Dani traditional pottery art seemingly remains unexamined. Drawing motivation from the tourism exploitations of Sirigu pottery art and its significant contributions to the local economy of the people of Sirigu as herein referred, the study sought to examine selected traditional pottery wares produced in Dani to reveal their cultural tourism potentials. 


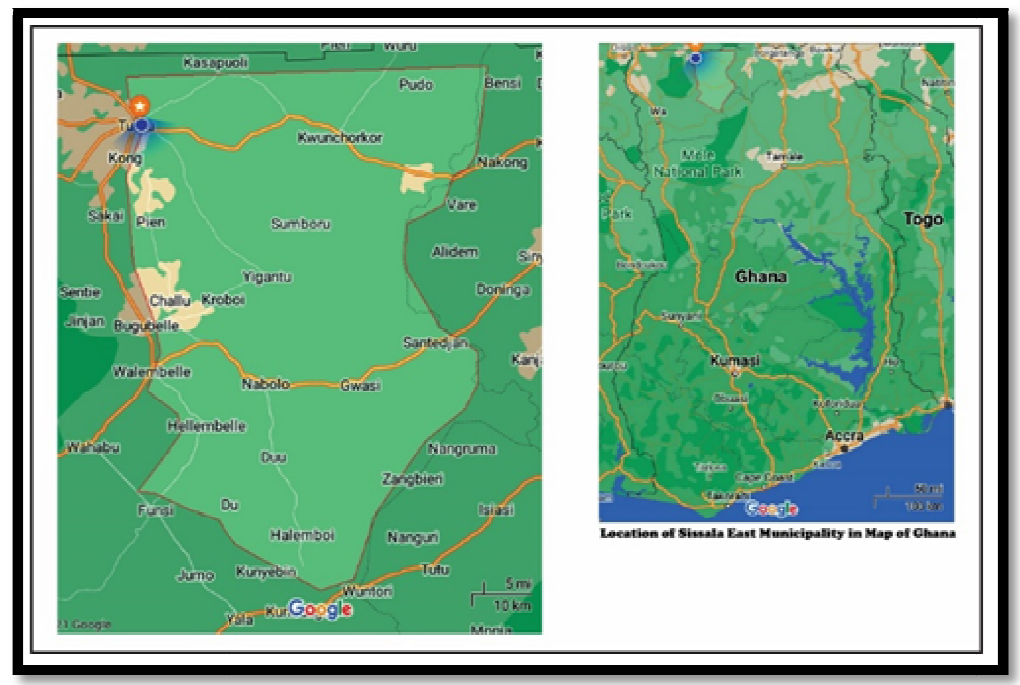

Figure 1: District Map of the Study Area

Source: Google Map, 2021

\section{Review of Related Literature}

\subsection{Conceptual Framework of the Study}

The study was premised on the concept of cultural tourism. Cultural tourism is an area with long-standing history (Vučetić, 2011) and lends itself to the harmony between two fields; culture and tourism as observed in Figure 2, whereby, the former serves as a fertile ground for the latter to strive. Historically, cultural tourism, as a term, emerged from a combination of the two concepts culture and tourism, which, by the end of the twentieth century, many countries considered as one of the most desirable developments in tourism (Al-Ababneh \&Masadeh, 2019). Tighe (1986), as cited in Zhang (2011) is of the view that cultural tourism began to gain recognition as a distinct product category of tourism in the late 1970s when tourism marketers and tourism researchers became aware that some people traveled specifically to gain a deeper understanding of the culture or heritage of a destination. Other studies corroborate that cultural tourism came about as a result of the urge to satisfy the curiosity of people (tourists) in seeing other people in their authentic environments as well as viewing the physical manifestations of their lives as expressed through arts and crafts, music, literature, dance, food and drink, play, language, and rituals (Dewar, 2005; as cited in Ngozi \& Chinonso, 2016; Jafari, 2000; as cited in Pratt \& Tarlow, 2014). Cultural tourism is one of the largest and fastest-growing global tourism markets where arts and culture are the vital constituents (Bhatta, 2016; Richards, 2007; as cited in Asmah, Mate \&Daitey, 2016). OECD (2009), as cited in Bhatta (2016) advances that the impact of culture on tourismanchors on the growing relationship between tourism and culture, and how culture and tourismhave together become major drivers of destination attractiveness and competitiveness.

The conceptual tenets of cultural tourism, in terms of scope and definition, have received many a scholarly opinion. According to Zhang (2011), cultural tourism is another form of tourism that involves cultural elements. These cultural elements relate to either tangible or intangible embodiments of the culture of a group of people including but not limited to; language, literature, traditional pottery art, costumes, native food, traditional festivals, carvings, basketry, leather products and others. The embedded satisfactions and new knowledge inherent in such cultural elements form the basis of either attracting tourists or motivating people to travel to such places (Mckercher\& du Cros, 2002). Ababneh and Masadeh (2019, p.110) posit that:

Cultural tourism has been technically defined as all movements of persons to specific cultural attractions, such as museums, heritage sites, artistic performances and festivals outside their normal place of residence (ATLAS, 1991) and conceptually defined as the movement of persons to cultural manifestations away from their normal place of residence, with the intention to gather new information and experiences to satisfy their cultural needs (Richards, 1996).

Both the technical and conceptual perspectives stated about cultural tourism point to the movement of people from one place to another to acquaint themselves with fascinating aspects of the culture of a group of people expressed through arts and crafts. In the considered view of Şengün (2011), cultural tourisminits broadest definition refers to travels directed toward experiencing the arts, heritage and unique or special character of a place because of the cultural stimulation of its arts (galleries, studios, performing and visual arts); cultural activities (festivals, celebrations, rituals, events); and physical heritage (buildings and environments). Studies further concur that cultural tourism connotes any journey inspired wholly or partly by the interest in the historical, artistic, scientific, or lifestyle/heritage offerings of a community, region, group or institution (Walker \& Walker, 2011; as cited in Ngozi \& Chinonso, 2016; Silberberg, 1995; as cited in Zhang, 2011). This suggests that the uniqueness of cultural products such as traditional pottery wares and their embedded inspirations and repositories could trigger the movement of people from their cultural origins to acquaint, educate and entertain themselves with such interesting new cultures.

The conceptual underpinnings proffered about cultural tourism find expressions under three main dimensions such as; tourism-derived, motivational-derived and experiential-derived (Zhang, 2011). While tourism-derived dimension 
views cultural tourism as a form of special interest tourism where culture constitutes the grounds of tourists' attraction; motivational perspective sees cultural tourism as an internal and/or external force of culture that satisfies tourists' wants and needs. On the other hand, experiential angle of cultural tourism opines thattourists want to get educated by experiencing culture in their journey. The study, therefore, narrows the scope of cultural tourism to mean a type of tourism destination with unique and captivating tangible cultural products of a people such as; traditional pottery arts and their embedded rich intangible oral historicity which have lasting potency to attract the patronage of many tourists. Premised on the concept of cultural tourism as espoused, the study seeks to examine the cultural uniqueness and relevance of Dayi traditional pottery products to establish their tourism potentials.

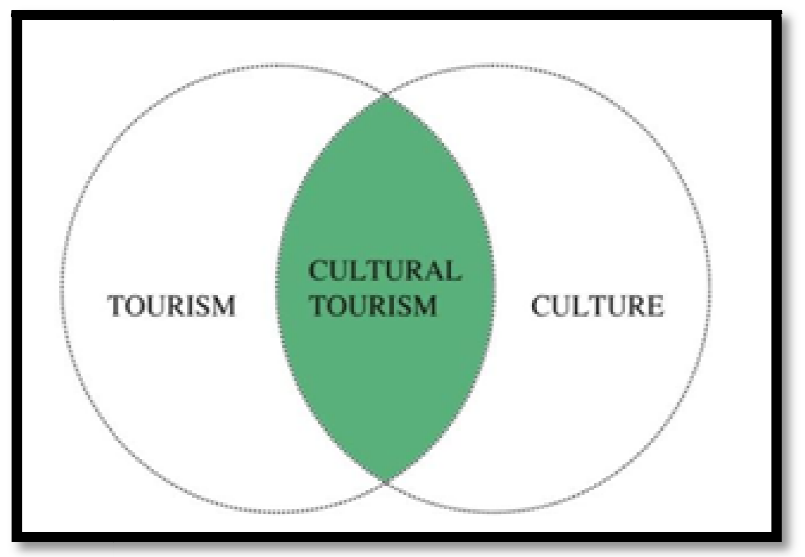

Figure 2: Diagrammatic Representation of the Concept of Cultural Tourism Source: Aleksa Vučetić, 2011

\subsection{Tourism Potentials of Handicrafts (Traditional Pottery Art)}

Handicrafts, such as traditional pottery art, form part of the tangible culture of indigenous people. They are uniquely defined as products made without the use of sophisticated tools that depict the cultural traits of a specific group of people at a particular given time (Zargham, 2007). The associated cultural attributes and utilities of handicrafts (for instance, traditional pottery receptacles) make them elements that engender cultural tourism. According to Sirika (2008), the cultural practices of indigenous people such as colourful ceremonial celebrations and fascinating ethnic arts and crafts are promising sources of cultural tourism. When the cultural elements of a society are enthralling, puzzling and thoughtprovoking, they stand to attract many tourists from different cultural orientations, thereby, making such a place a tourism destination. For instance, the Dorzé village has become an endowed worthwhile cultural tourism attraction destination in southern Ethiopia through the production of handcrafts using hand weaving techniques, traditional pottery methods; the presence of elephant-shaped house building; cultural festivals, traditional music and instruments; the process of making food from false banana trees and culinary experiences (Tegegn, Amsalu \& Tefera, 2020). In Ghana, several studies have revealed that the cultural and philosophical designs notable of Sirigu pottery and arts remain the major reason behind the high inflows of tourists to Sirigu in the Upper East Region of northern Ghana (Wemegah, 2009; 2014; Asmah, Mate \&Daitey, 2016; Sheldon, 2016; Yussif\& Adu-Gyamfi, 2017, Yussif, Adu-Gyamfi \& Tabi-Agyei, 2018).

Traditional pottery products of indigenous cultures across the globe continue to become attractive tourism objects. It is so because, pottery products form a distinctive part of the visual culture of indigenous people in most parts of the world (Asante, Adjei \& Opoku-Asare, 2013; Navei, 2020) and therefore have interesting underpinnings of which tourists from varied cultural backgrounds are interested in unraveling. Traditional pottery wares are not only shaped for functional/utilitarian purposes but also for social and non-utilitarian or symbolic values (self-expression and identity marks) which could be sources of tourism attraction (Sirika, 2008). In addition to preserving traditional knowledge, skills and technologies, handicrafts production (such as pottery products) provides vocation and livelihood opportunities; satisfies the aesthetic, utilitarian and spiritual/ritual needs of the local people as well as contributes to the development of tourism as local and international tourists patronise these authentic Ghanaian handicrafts as a gift and decorative items (Segbefia, 2009). Tegegn et al. (2020) are also of the view that cultural pottery and the pottering processes have recognisable cultural tourism attraction potentials (Tegegn et al., 2020). This comes at the back of the fact that cultural pottery products and their production processes are uniquely peculiar to the tenets of the culture and the local ingenuity of a particular group of people. As a result, tourists find such wares to be interesting based on their utility and sociocultural symbolisms. In a study titled; creative cultural tourism as a new model for cultural tourism, Al-Ababneh and Masadeh (2019) establish that many tour operators often develop tourist packages that combine several cultural activities such as; arts and crafts (pottery, sculpture, painting and Textiles). Ngozi and Chinonso (2016) concur that cultural handicrafts such as; basketry articles, carved objects, bronze cast objects, figurines, pottery wares, iron objects and others promote tourism development. Zargham (2007, p. 1014) concurs that handicrafts do not only serve as the catalyst to national tourism sustainable development but could also serve as a "cultural tourism destination, and a champion for the development of a strong and vibrant tourism sector which contributes to sustainable economic growth, job creation, poverty alleviation, and protection of the natural and cultural heritage". This implies that a community that engages in the production of culturally embedded traditional pottery wares, if promoted, has the potential of attracting tourists thereby making such a community a tourism destination. 


\section{Methodology}

The study adopted a qualitative approach whereby data collection and analysis were influenced by descriptive design. Qualitative descriptive design "is a straight descriptive summary of the informational contents of data organised in a way that best fits the data (Sandelowski, 2000, pp. 338-339). The choice of qualitative descriptive design ensured accurate description, explanation and interpretation of the perceptions and lived experiences of the respondents and events surrounding Dani traditional pottery art and its cultural tourism potentials. Inherent with qualitative descriptive design, data for the study were collected through unstructured interviews, field observation and photography. The population of the study consisted of the rural potters (women) and opinion leaders of Dani community, members of the Sissala East Municipal Assembly, Regional officials of the Ghana Tourism Authority in The Upper West Region of Ghana and officials of Centre for National Culture in Sissala East Municipality in The Upper West Region of Ghana. With the use of homogeneous and expert purposive sampling techniques, a total number of twenty (20) respondents were selected comprising: the Chief of Dani; three (3) elders in Dani; the Queen mother of Dani; eleven (11) practising potters in Dani; Assembly Member of the Area; the Municipal Chief Executive of Sissala East Municipal Assembly, the Upper West Regional Manager of Ghana Tourism Authority and the Sissala East Municipal Director of Centre for National Culture. The potters' category of respondents were informants with at least thirty years of pottery experience who shared with the study through interviews, their lived potting repertoire of experiences and the philosophy and cultural relevance of Dani pottery wares. Field observation and photography were additionally utilised as data collection instruments to witness and capture photographs of the traditional pottery wares produced in Dani for purposes of authenticating the oral accounts of the potters. Also, the views of the other respondents (Chief and Queen Mother of Dani, Assembly Member of the Area, Municipal Chief Executive of Sissala East Municipality, the Upper West Regional Manager of Ghana Tourism Authority and the Sissala East Municipal Director of Centre for National Culture) were sought on how to provide the needed infrastructural and technical support to ensure that Dani traditional pottery art is developed into an attractive tourism destination for global patronage. Findings that emerged from the data were thematically analysed, discussed and described to ensure clarity and contextual understanding of the study in its entirety. With the entry into the study area, collection and the handling of data, the study administered informed consent forms to all respondents. Guided by the consent entered with the respondents, the study strictly protected the confidentiality of the data gathered as well as the anonymity of the respondents. However, the use of pictorial findings and attribution of direct accounts of some of the respondents were revealed in the study under the absolute consent of such respondents.

\section{Findings and Discussion}

\subsection{Cultural Background of Dani Traditional Pottery art}

The people of Dani have rich cultural ideals that underpin their social, political, cultural and religious lives. Most of these cultural ideals of the people of Dani ride on the back of traditional arts, particularly pottery art. Despite globalisation and its negative effects on indigenous Ghanaian arts and culture, the people of Dani have since the evolution of the community strived to preserve and promote their cultural practices through the use of traditional arts. The potterinformants consensually posited that pottery art is an indigenous handicraft of the ancient women of Dani through which basic receptacles such as; storage vessels, cooking pots, terracotta figurines, earthen bowls and many others were produced to serve the sociocultural, sociopolitical and religious needs of the forebears of the community way before the Iron Age. The potters further advanced that the aforementioned pottery receptacles characterised the cultural evolution of Dani people and their production and utility in this contemporary era confirm the cultural relevance of pottery art to the people of Dani. The potters epitomised that, it is a cultural responsibility of relatives (women) to contribute a collection of assorted pottery wares (pots, bowls and others) to a daughter entering into a fresh traditional marriage. The collection of pottery wares given to a newly married daughter is part of measures taken to resource her at the early stages of her marriage so that she does not have to always rely on others for basic cooking utensils to execute her daily feminine domestic responsibilities. As she completely settles down in her matrimonial home, she is supposed to rely on the potting skills acquired from her mother during her upbringing to add more of the pottery wares when the need be. Also, during traditional funerals, water meant for the bathing of a dead body is symbolically boiled in a classified pottery ware known in Sissali as Pipoi-Bunbunufor the bathing process. And, a significant number of the most powerful personal and communal deities in Dani, particularly koglor, still being revered by the adherents of African traditional religion, are made of pottery products. As a result of the cultural relevance of pottery art, the people of Dani have since preserved the art in the generational life of the community. This, the women did by actively making pottery art a daily household activity. The rural potters (women) in Dani variously affirmed that they owe it a duty to preserve the traditional arts, particularly pottery, which was once cherished and revered by their forebears. In this contemporary era, Dani traditional pottery art has huge economic benefits to the rural potters in addition to its primary social, political and cultural relevance. As a result, Dani has conventionally become a famous traditional pottery hub where many people in Sissala East Municipality, Upper West Region and Ghana by extension do visit to purchase traditional pottery receptacles to meet their sociocultural, socioreligious and sociopoliticalneeds.

\subsection{Tourism Potentials of Dani Traditional Pottery Art}

Dani traditional pottery wares have fascinating appeals, cultural significance and are repositories of philosophical and totemic statements consistent with the daily lives of Dani people. The cultural relevance and philosophical repositories of Dani traditional pottery wares are founded largely on their design and decoration semiotics. Besides, the 
contexts in which the pottery wares are produced and utilised in Dani culture make the wares representative of both the material and visual culture of people.

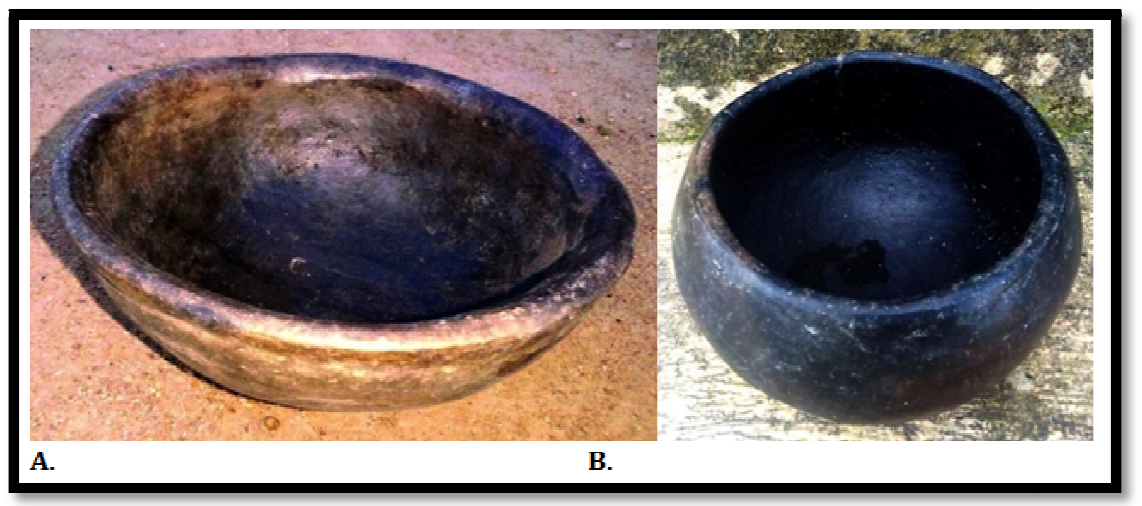

Figure 3: (A\&B): Hanneh(Earthen Bowl)

(Source: Fieldwork)

The study found earthen bowls (Figure 3A\&B) known in Dani ashanneh (singular) and han-seh(plural) to be the indigenous bowls used in serving meals in Dani. Traditional meals such as Kuli in Dani and Tuo Zaafi(T. Z.)in Ghana is usually servedin a particular type of hanneh observed in Figure 3A, whereas, the soup is served in a specially designed kind of hanneh exhibited in Figure 3B. Besides han-seh being the first basic bowls produced and utilised since the ancient culture of Dayi, hanneh is revered as the totem of the indigenes of Dani and other cluster of Sissala communities with the same ancestral lineage known as the Hanviaclan (the earthen bowl totemic clan). The reverence of hanneh as a totemic element in the indigenous Dayi culture is premised on the spiritual relationship that exists between the hanneh (earthen bowls) and the souls of Dani people. Although, the exact associated historicity behind hanneh totemism in Dani culture was not made known, the study however established that during traditional naming ceremony of a baby in Dani, the ritual meal; Kuli (T.Z.) and soup, is servedin a calabash and a new hannehrespectively. The ritual meal is then sent to an existing communal location which contains all the old han-seh (Figure 3A\&B) used for traditional naming ceremonies in the life of the community. As part of the rituals, only children are allowed to jointly eat the ritual meal after which the hanneh is added to the existing old ones. The potters explained that the hanneh (earthen bowl) represents the soul of the newborn and at death, a new hannehis ritually crashed to signify the death of the person and dissolution of the bond between the dead and the living. Therefore, the reverence of earthen bowl as a soulmate and clannish totemic symbol prominently form the cultural basis of Dani traditional pottery art.

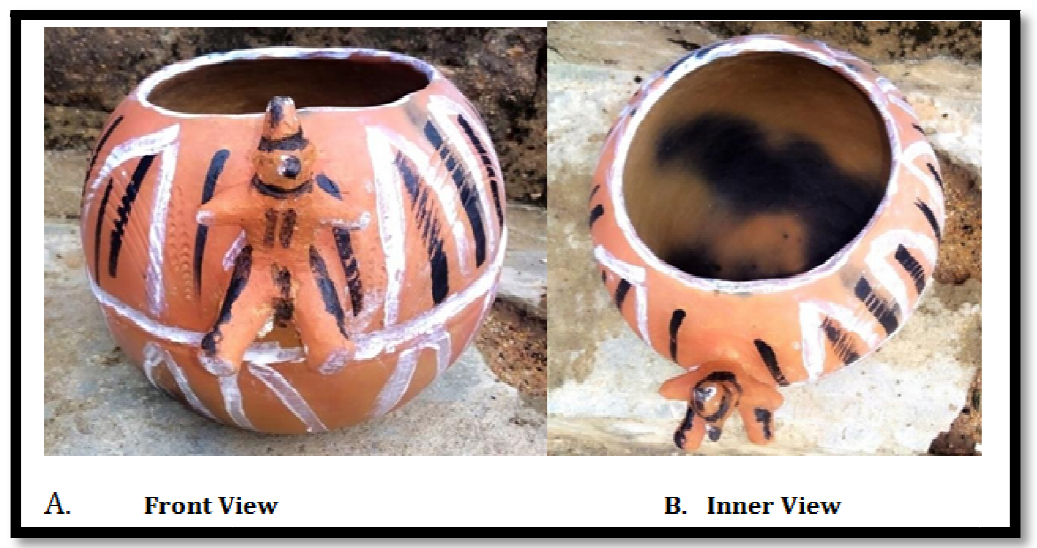

Figure 4: (A\&B): Pipoi-Bunbunu(Traditional Ware Used for Washing Corpses) Source: Fieldwork

Pipoi-Bunbunu(Figure $4 \mathrm{~A} \& \mathrm{~B}$ ) is a traditional pottery ware used in the ritual bathing of corpses as required in the customs and traditional burial rites in Dayi culture. The name pipoi-bunbunuis derived from its design as pipoigenerallyrefers to pot in Dani and bunbunu, contextually means without neck. Therefore, pipoi-bunbunumeans a pot without a neck. Although Christians and Islamic converts nowadays use contemporary buckets (plastic or metal) for washing corpses before burial, the potters emphasised that pipoi-bunbunu(Figure 4A\&B) is the only culturally acceptable ware used in the ritual bathing of corpses for traditional burial rites since the evolution ofDani community and in this contemporary era. The strict adherence of this practice by the practitioners of African traditional religion in Dani is mainly to ensure a smooth transition of the soul of the deceased person unto the ancestral land. The use of classified pottery ware for ritual bathing of corpses during traditional burial rites as a mandatory cultural requirement in Dani was similarly found in the case of Charia culture in the Upper West Region of Ghana where Gbaali (a pottery ware) remains "the only appropriate container customarily used in washing (bathing) dead bodies of African traditional believers in Charia to ensure a smooth transition unto the ancestral world" (Navei, 2020, p.14). 
A cursory view of the ware (Figure 4A\&B) reveals a modeled figurative representation of a corpse illustrating how a corpse is staged and mourned during traditional funeral rites in Dani culture as ascertained by the study. It was further revealed that the black and white renditions (marks) on the wares (Figure 4A\&B) are not only meant for decoration but the black marks illustrate the grief and sorrow associated with death whereas the white renditions reveal joy and reassurance that the deceased person has another opportunity to live once again in the ancestral world thereby affirming their belief in life after death.

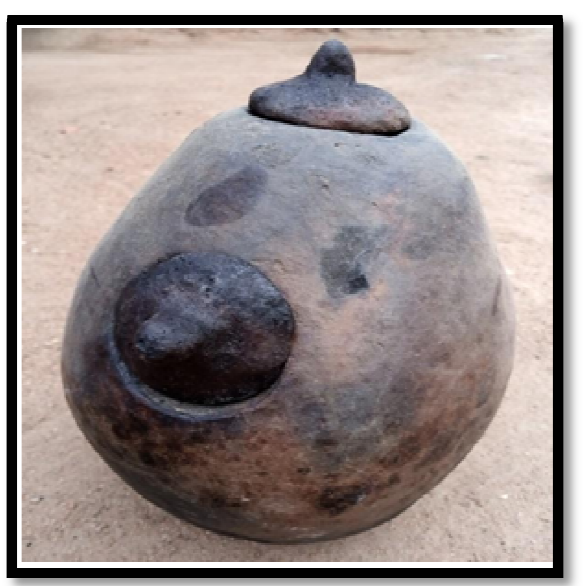

Figure 5: Vuuri (Grain Storage Facility) Source: Fieldwork

In Dani culture, Vuuri (observed in Figure 5) is an indigenous grain storage facility in other words known as a silo. Vuuri comes in various sizes such as; huge, medium and small with the huge size used to store large quantity of millet meant for the consumption of the entire extended family, particularly, during the lean season. It was established by the study that Vuuri occupies a significant portion of the indigenous culture of the people of Dani. In time past, after a successful harvesting season, a significant quantity of the entire family harvest (millet/ grains) is stored in Vuuri. A male family member is assigned to take charge of rationing the grains to all the women (wives) of the family at a given interval of not less than a week. The women are enjoined to manage their rations for the given period else they, together with their children, would have to endure hunger for any mismanagement. It was further emphasised that under no circumstance should any family member open the vuuri and fetch the grains unless under rare instruction of the assignee only. Any other family member who fetches grains from the vuuri either than the usual assignee is deemed to have committed theft. As for women, it is a taboo for them to open the vuuri let alone deepening their hands into it. One of the women fearfully stated that:

No! No! No! Under no circumstance should a woman secretly fetch millet from vuuri [silo] either by herself or through the wrong person. It amounts to an unpardonable crime of stealing against the vuuri. A theft against the vuuri could lead to death of such a woman or her children unless early confession or when a seer reveals such an abominable act to the husband of the woman on one of his regular visits to soothsayers. (H. Kunkun, personal communication, January 11, 2021)

However, the study found that the introduction of sacks and other grains storage facilities in this contemporary era has subjected the use of vuuri to few indigenes in Dani. That notwithstanding, the potters explained that as a way of revitalising their material culture, vuuri is potted in a miniature form (Figure 5) as a deliberate attempt to educate the current and future generations of some of the revered tangible cultural elements of the people of Dani.

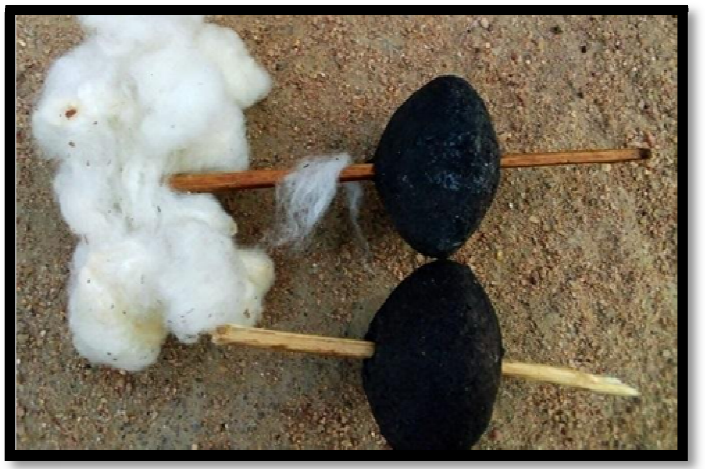

Figure 6: Gen-Daa (Cotton Spinning Device) Source: Fieldwork

Figure 6 displays pottery artefacts known in Danias gen-daa. They are cotton-spinning devices developed by the forebears of Dani community to process cotton wool into rolls of thread. It was established from the potters that gen-daa (Figure 6) is a cultural relic as far as the foundation of the traditional dress fashion culture of the people of Dani is 
concerned. The potters explained that in the olden days when local ingenuity remained the only available technology for addressing the necessities of their forebears, gen-daa was specifically developed and deployed in spinning cotton wool into rolls of thread and subsequently hand-woven into fabric for the making of garments known in Dayi as Sisaala geri (Sissala dress -smock, wraps and others).

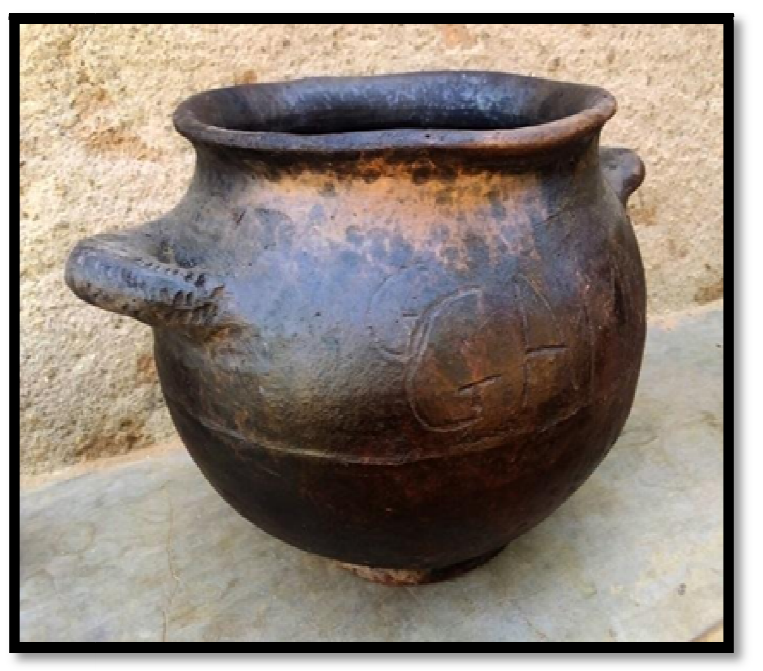

Figure 7: Kpaali (Bucket)

Source: Fieldwork

In indigenous Dani culture, Kpaali (Figure 7) is a bucket used for bathing. Before the invention of plastic and metal buckets, Kpaaliplayed the functions of a bucket. The potters demonstrated that a husband's bathing water was always served in it and carried by the wife into the bathroom for him to take a bath. After the husband was done with the bathing, the wife would retrieve the bucket (Kpaali) for her use too. Besides using Kpaalias a bucket for bathing, its bigger version could be used as a container for what the potters described as beating (rigorous stirring) of fried and hand-milled shea (Vitellaria paradoxa) nut paste during the preparation of shea butter. In seeking to establish whether or not Kpaalihas any relevance in this contemporary era, the potters indicated that the emergence of plastic and metal buckets has displaced the use of Kpaali. The potters attributed this development to durability, ease to use, cheap availability, and modernity as far as the use of plastic and metal buckets in Dani is concerned. However, the potters deemed it necessary to produce Kpaalias a way of preserving the tangible cultural material for the current and upcoming generations of the people of Dani.

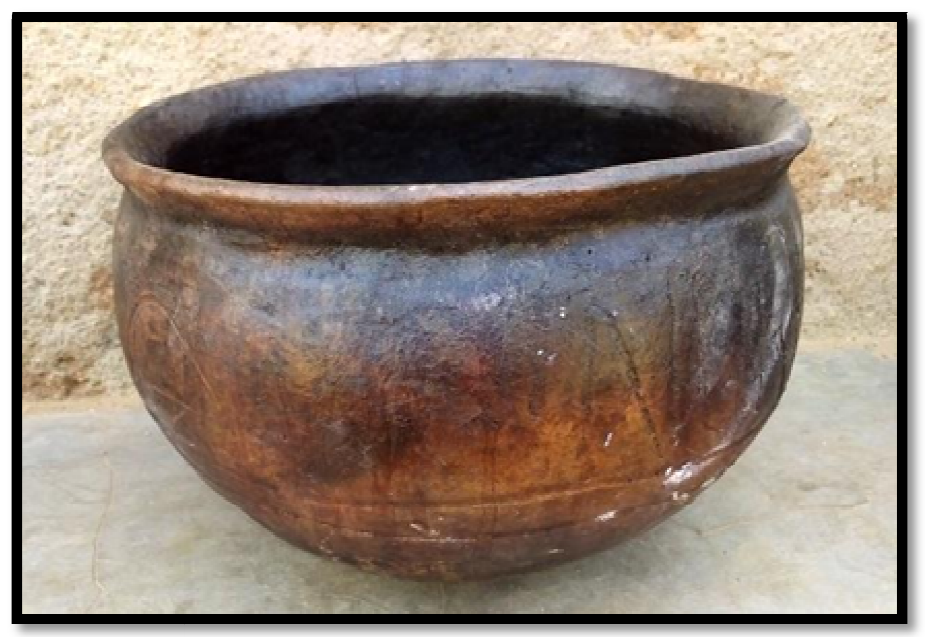

Figure 8: Nuu-Hali (Shea-Nuts Roaster)

Source: Fieldwork

Nuu-hali, as displayed in Figure 8, is another traditional pottery ware produced in Dayi. The potters posited that in ancient Dani culture, Nuu-hali served as a locally potted chamber for the roasting of shea (Vitellaria paradoxa) nuts for further processing into shea butter. Although Nuu-hali (Figure 8) could be used for other sociocultural functions, the potters consensually stressed that its main function is for the roasting of fragments of shea nuts. The ware is put to use after shea nuts have been pulverised into suitable fragments using mortar and pestle and subsequently poured into it while it is on fire and constantly stirred to ensure that all the fragments of shea nuts are well roasted. The potters indicated that with the presence of iron pots in this contemporary era, Nuu-haliis no longer in use as before. However, the potters were of the view that the cultural relevance of Nuu-haliregarding shea butter processing in Dani could not be shortchanged with contemporary technological inventions. This is based on the case that the production of shea butter is an ancient practice in Dayi. The potters described shea butter as an invaluable indigenous edible oil prepared locally 
(without mechanical means) and utilised for the cooking of various meals; as a pomade for skincare and as a mixing agent for some herbal medicines. The fact that Nuu-hali was instrumental in shea butter production, particularly during the premetal age of Dani culture, forms the paramount basis for which the ware is being potted in this contemporary era to highlight its cultural relevance.

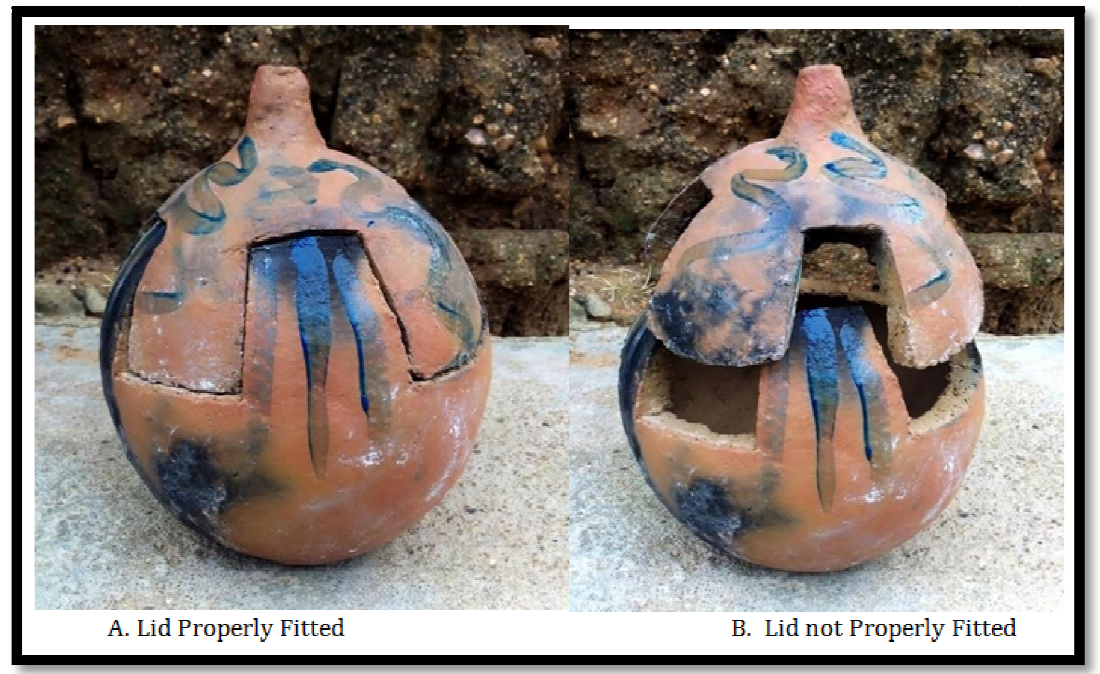

Figure 9(A\&B): Gaara-Waasuru (Thieves Do Not Open) Source: Fieldwork

Another pottery ware with tourism potential produced in Dani is known as gaara-waasuru(Figure 9A\&B). The potters posited that gaara-waasuruisan indigenous ware used by Dani women, particularly in the olden days, for the storage of precious belongings and valuables. While the bigger version of the ware (Figure 9A\&B) was used as a safe wardrobe, trunk or bag in keeping the valuable dresses and clothes of Dayi women in time past, its smaller versions are used in storing rarely prepared or obtained ingredients such as; dawadawa (special soup ingredient prepared from African locust beans), smoked fish and others. The potters explained that when valuables are stored in gaara-waasuru, they are safe from dirt and contamination due to its fitting lid. The ware is named gaara-waasuru, which in Sissali literally means thieves do not open, due to its intriguing design. Gaara-waasuruis such that when the lid is lifted or opened and has to be closed, that must be done with due diligence. The ware has carefully designed cut-ins of varied sizes rounding both the ware and its lid that fittingly interlock when properly closed. The varied sizes of the cut-ins on the ware proportionally correlate with the lid, such that the lid only fits in when placed at its original position (Figure 9A). But, with a change in the original position, the lid would not fit into the ware as observed in Figure 9B. The technicalities associated with the ware make it difficult for thieves who are often in hurry and impatient to properly close the lid after stealing from the ware thereby immediately exposing the theft to the owner. In other instances, the thief is caught in the delayed process of trying to properly close the lid. Since thieves do not want their thievery to be tracked and/ or being caught, they do desist from tempering with items secured in the ware. Hence, its gaara-waasuru (thieves do not open) nomenclature.

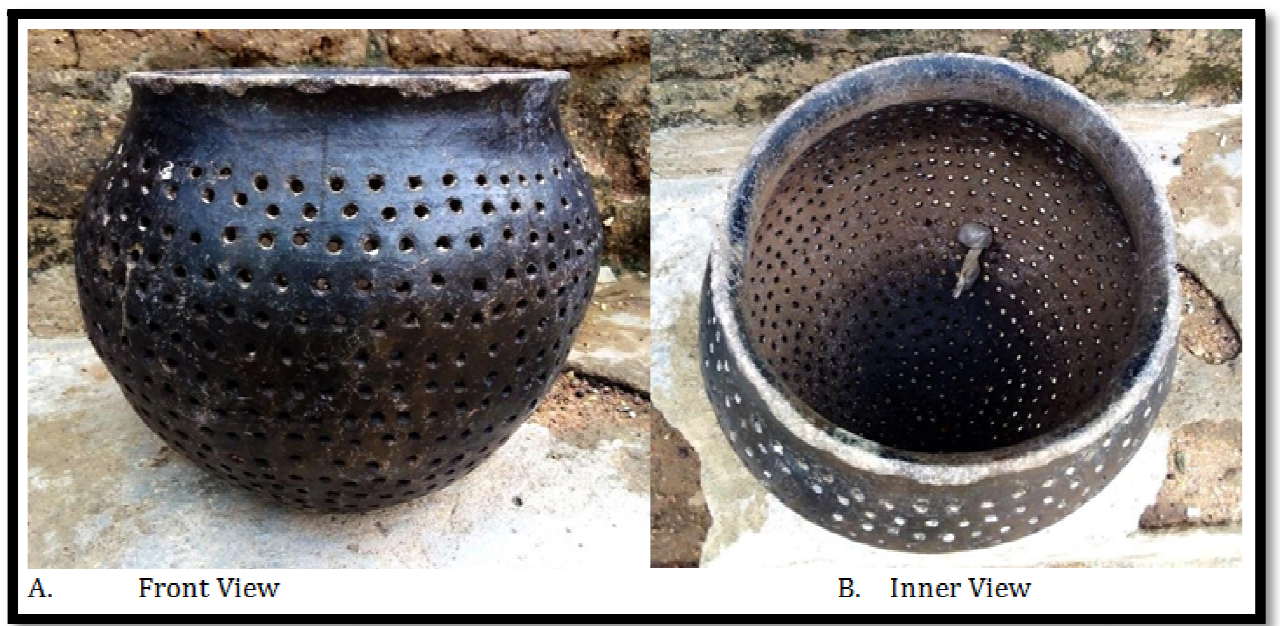

Figure 10(A\&B): Chulia (Pottery Ware Used In Washing and Sieving

Boiled and Dehulled African Locust Seeds

Source: Fieldwork

In Dani culture, cheleh (Figure 10A\&B) is strictly a women's domestic utensil used in washing and sieving boiled and dehulled African locust (dawadawa) seeds for further processing into what is locally called chua (a local soup ingredient) in Dani and generally known as dawadawa in Ghana. Whereas cheleh is also used to smoke meat/fish for 
preservation for future use as similarly observed by Navei (2020) in the case of Charia culture, the rural Dani potters added that cheleh is equally strictly used in roasting certain specific type of herbs for classified herbal medication and spiritual fortification. The ware is strictly referred to as women's domestic utensil not only because it is mainly used by women but it is a taboo for a man to ever deep his hand into the ware. When a Dani man does deep his hand into the ware, he stands to lose the blessings associated with manhood in areas such as; hunting, farming, among others. The perforations that feature the entire body of the ware (Figure 10A\&B) have conceptual underpinning either than for decorative reasons. They serve as outlets for sieving out the chaff of boiled and dehulled dawadawa seeds during washing leaving the cleaned leftovers of the boiled seeds/beans for further processing into the delicious soup ingredient known locally as chua.

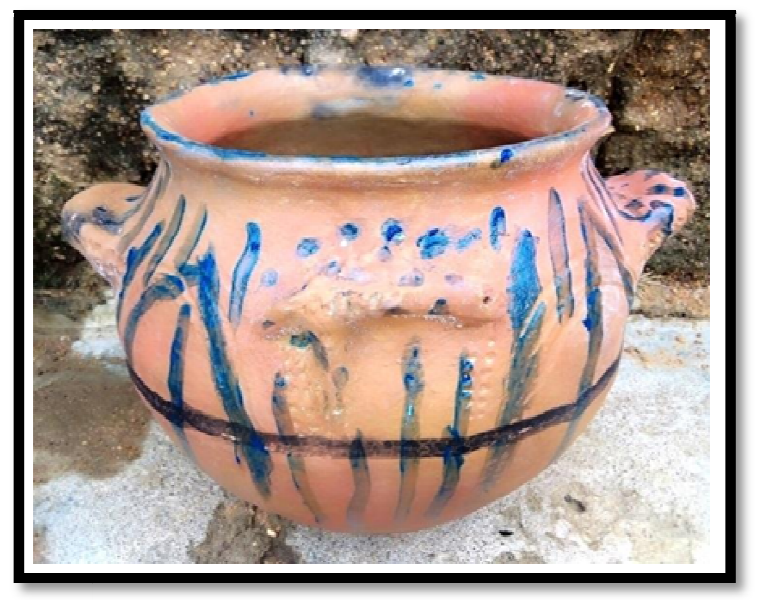

Figure 11: Gama (crown bird) Totemic Decorative

Source: Fieldwork

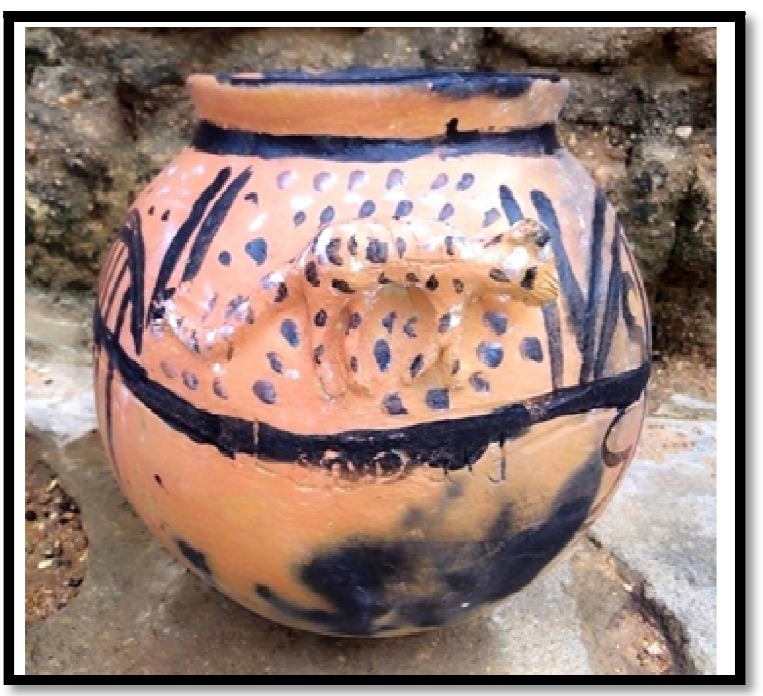

Figure 12: Kpei(Leopard) Totemic

Decorative Design

Source: Fieldwork

The exterior walls of Dani traditional pottery wares provide suitable platforms for the potters to symbolically reveal their well-revered culturally related totemic motifs. The study observed that totems of some of the potters were incorporated into the design and decoration semiotics of Dani traditional pottery art as typified in Figures 11 and 12 . In the case of Figure 11, the ware is decorated with a symbol of crown bird locally known as gama, thereveredtotem of the woman who potted the ware. The vertical strokes registered on the ware (Figure 11) are indicative of trees suggesting a forest. Also, Figure 12 reveals a pottery ware decorated with a figurative model of kpei (leopard) also representing the totem of the potter who produced the ware. The potters interpreted the vertical strokes found at both ends of the leopard's figurative model (Figure 12) to mean trees that engulfed the leopard. Coincidentally, both the gama (crown bird) and kpei(leopard) totemic clans have the same cultural root and this was well corroborated by the producers of the wares. The potters asserted that in the olden days, two of their great forebears were once pursued by their enemies (raiders) where they narrowly escaped death but took cover under a tree for a short rest. During the resting process, they both slept off while the raiders who were still searching for them in the bushes got closer to their location. As they were fast asleep and oblivious that the enemies were fast approaching to kill them, gama (crown bird) which was on the tree under which they slept, broke a dried piece of stick and it fell on one of the men waking him up from his sleep to the realisation that 
their enemies were fast approaching to kill them. He immediately woke up his other brother and been confused of where to pass, kpei (leopard) suddenly appeared from nowhere and led them to escape. Considering how the crown bird and the leopard saved their lives, they debated on which of the animals to revere as a totem. Upon a prolonged and irreconcilable debate, one opted for gama (crown bird) and the other chose kpei (leopard) as separate totems where they both vowed that they, including their generations unborn, respectively, forbid the killing and eating of gama (crown bird) and kpei (leopard). This gave birth to Gamviara (crown bird's totemic) clan and Kpeiviara (leopard's totemic) clan of the Sissala ethnicity.

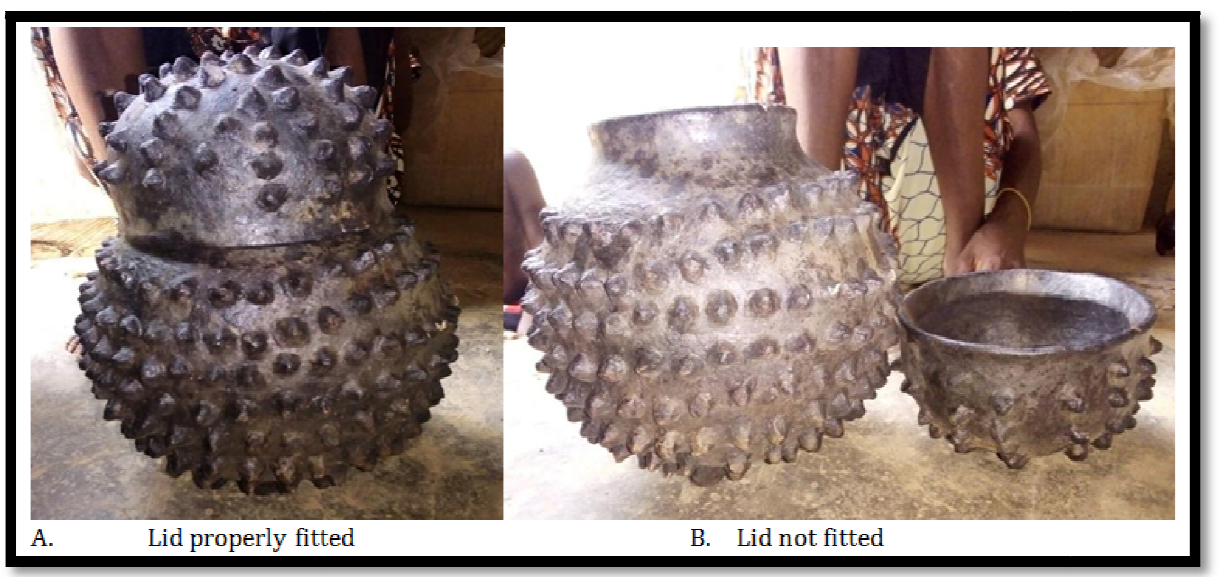

Figure 13 (A\&B): Niiha (Ritual Pot)

Source: Fieldwork

The pottery ware as observed in Figure 13 A\&B is known in Dani culture as Niihaandupheld as a custodian of spiritual powers. Niiha is a ritual pot with potent and enormous spiritual functionality. Its powers are drawn from ritual processes of spiritual imbuement for a specific realm of purpose. The potters revealed that Niihacould be adopted as a personal or communal deity for protection against evil forces. It was further ascertained that Niihapot could be ritually prepared and mounted on an elected fox stake in a farm to protect the crops of the farm against destructive spiritual forces cast by evil doers as well as bless the farm with bumper yield. One of the potters explained the powers of Niiha pot as follows:

Niiha has no mercy for anything evil or any individual that poses threats to the success of crops in a farm. Even, when a menstruating woman, who is deemed unclean, knowingly or unknowingly enters a farm that is under the protection of Niiha, she suffers her portion of punishment. Niiha would cause the menstruation not to ever cease until such a time that a confession is made to the owner of the farm who does the necessary rituals to save the woman. (K. N-winharijin, personal communication, January 11, 2021)

A cursory view of the ritual pot (Figure 13A\&B), particularly the surface decorations, reveal carefully repeated dark embellished spikes deliberately put in place to achieve a combined fearful and scary look. The potters explained that the spikes serve as outlets through which the spiritual ammunitions embedded in the ware are discharged to repel and/ or conquer all evil forces.

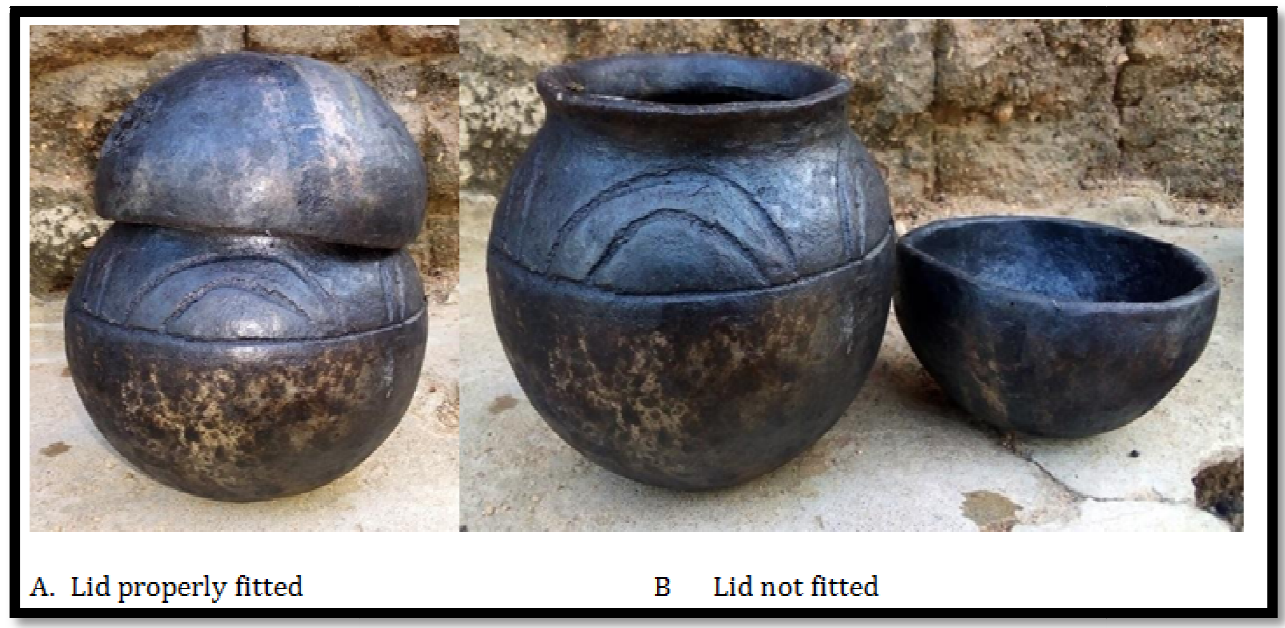

Figure 14(A\&B): Koglor (Mystical Pot)

Source: Fieldwork

Koglor(Figure 14A\&B)is a personal spiritual deity but available for communal benefit. Its time-tested spiritual robustness is usually evoked to rescue the lives of people suffering from spiritual ailments. The study established that Kogloris a mystical pot with the spiritual foresight to prognosticate the forces behind prolong and mysterious ailments 
suffered by any inhabitant of Dani community. According to the potters, the pot comes with a fitting lid as observed in Figure $14 \mathrm{~A} \& \mathrm{~B}$ and houses the mystical spiritual herbs. It is placed on the head and tightly gripped with both hands, and through incantations, the carrier of the pot is spiritually possessed by the mystical foresight of Koglorand led through dangling to reveal evil elements (trees, rocks, charms, evil persons, and others) responsible for the person's ailment. When such an evil element is identified, the mystical spirit of Koglor communicates in tongues through its carrier to the elders present, the cause of the person's ailment and the healing processes. Due to its potency to predict all evil forces behind ailments and the possibility of creating marital, family and inter-communal conflicts, the spiritual powers of Koglor(mystical pot) are sparingly evoked. Even when its spiritual powers have to be evoked to save a life, informed consent has to be entered between its owner and the person seeking to evoke the powers through a word of vow.

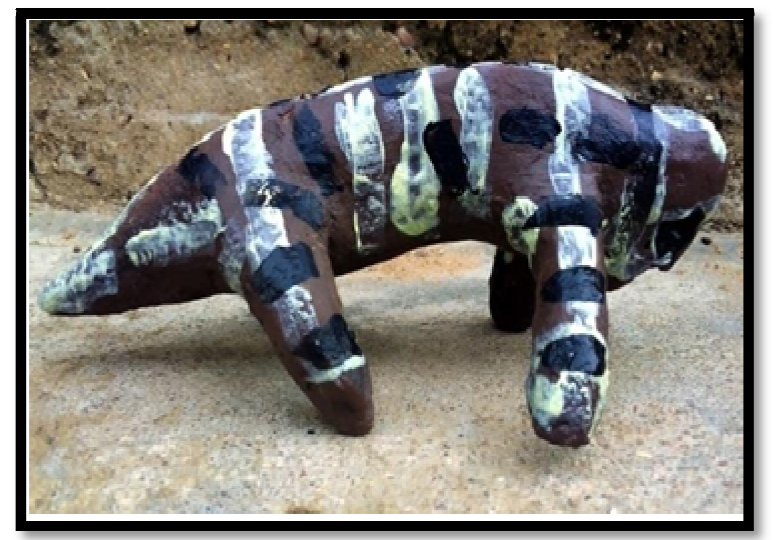

Figure 15: Female Gbeligbene (Chameleon) Terracotta FigurineFigurine Source: Fieldwork

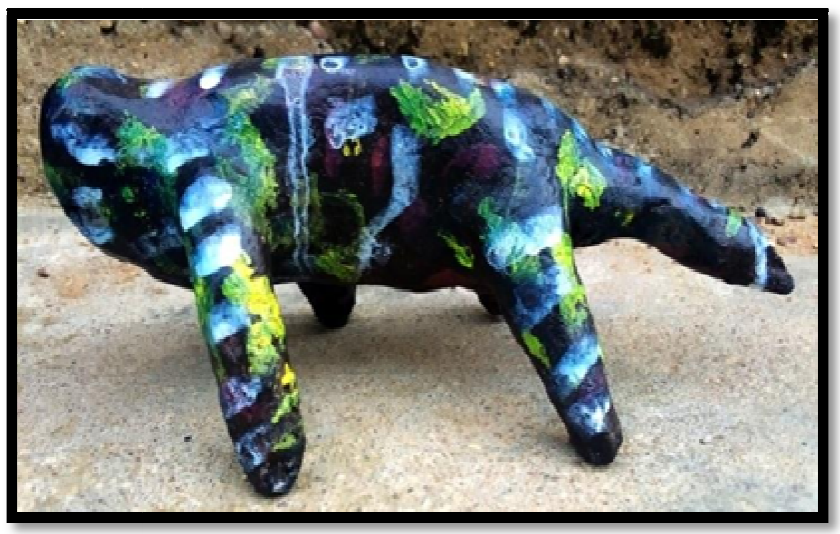

Figure 16: Male Gbeligbene(Chameleon)

Terracotta FigurineFigurine Source: Fieldwork

The potters in Dani are equally noted for the production of culturally related terracotta figurines. The colourful terracotta figurines in Figures 15 and 16 represent female (Figures 15) and male (Figures 16) chameleons. The potters explained that the chameleon terracotta figurines (Figures 15\&16) are not usually made for the sake of making but they are produced on specific request, particularly, when the chameleon spirit is to be initiated into a deity. In such instances, the person upon whom the revelation is made contracts a potter to produce the chameleon terracotta figurines (Figures 15\&16) for that purpose. The potters further revealed that the chameleon spiritual deity is not only associated with the people of Dani but it is a very popular deity found in Sissala communities to the extent that it has culminated into reincarnated Sissala names such as; Gbene, Gbemmie for male and Hagbene and Hagbiemmie for female). The chameleon terracotta figurines (Figures 15\&16) when ritually imbued into deity have the power to protect their custodian and ensure successes in economic, agricultural and other engagements. With such cultural and religious significance, the potters asserted that the chameleon terracotta figurines and other culturally related terracotta figurines (such as twins) are deliberately produced to preserve the cultural and religious relics of Dani people and for the admiration of tourists. The potters explained that the production of such figurines is necessitated by the supremacy of the global Islamic and Christian faiths and Western culture in contemporary Dani whereby the indigenous cultural and religious traditions of the community have severely been marginalised, if not thrown to the dogs.

\subsection{Stakeholders' Views on the Development of Dayi Traditional Pottery Art into a Cultural Tourism Destination}

The study found unanimity in the accounts rendered by the stakeholder-respondents regarding the development of Dani traditional pottery art into a cultural tourism destination. The stakeholder-respondents comprised the Chief and Queen Mother of Dayi community; the Assembly Member in charge of Dani community; the Municipal Chief Executive of 
the Sissala East Municipal Assembly who are all indigenes and residents of Sissala East Municipality and were well aware of Dani traditional pottery activities. Also, the Sissala East Municipal Director of Centre for National Culture and the Upper West Regional Manager of the Ghana Tourism Authority were among the key stakeholders contacted by the study. All the stakeholder-respondents variously and categorically indicated that the development of Dani traditional pottery art into an attractive tourism destination would be a step in the right direction. This consensual assertion of the stakeholderrespondents was influenced by the cultural uniqueness of Dani traditional pottery wares coupled with their embedded repositories of fascinating indigenous cultural knowledge of Dani people as herein revealed in the study (Figure $3,4,5,6,7,8,9,10,11,12,13,14,15 \& 16)$. The stakeholder-respondents vehemently argued that the development of Dani traditional pottery art into a cultural tourism site has trifocal benefits. These include: promoting the economic empowerment of the rural potters for decent livelihood; sustain, preserve and promote the tangible culture of Dani (Sisaala) people, and would also serve as a viable avenue for the mobilisation of internally generated funds for the Sissala East Municipal Assembly. In view of the aforementioned trifocal benefits of Dani traditional pottery art, the stakeholderrespondents variously pledged their support (infrastructural and technical wise) towards the transformation of Dani traditional pottery art into an attractive cultural tourism destination.

The Chief and Queen Mother of Dani as well as the Assembly Member of the area pledged to provide locally-based support such as; mobilising the people of Dayi into communal labour to support any infrastructural development of a tourists' centre in the community that might be initiated by either governmental agencies or Non-Governmental Organisations (NGOs). The Municipal Chief Executive and the Director of Centre for National Culture for Sissala East Municipality also pledged to liaise with the Upper West Regional Management of Ghana Tourism Authority to ensure that the needed infrastructural and technical support for the development of Dayi traditional pottery art into a vibrant cultural tourism destination is instituted without further delay. In creating the awareness of the Upper West Regional Office of Ghana Tourism Authority (GTA) to the cultural tourism potentials of Dani traditional pottery art, the study found that the GTA was eagerly ready to initiate a reconnaissance survey of the community to come up with the appropriate interventions, strategies and the way forward. The Upper West Regional Manager of Ghana Tourism Authority who granted an interview to the study explained that:

First of all, the authority will have to visit Dayi to interact with the community members, key stakeholders of the community, stakeholders of Sissala East Municipal Assembly and all who matter most. This would enable the authority to assess the pottery products and economic activities of the people of Dani and their priorities in order to plan with them how to achieve those priorities regarding tourism development in the area. Depending on the outcome of the engagements, for instance, if the pottery products qualify to be promoted by Ghana Tourism Authority, the authority would further engage the potters to identify their target market; facilitate study tours for the potters to visit similar traditional pottery producing establishments in Ghana to learn and exchange ideas. Also, the Authority would provide assistance to the potters to form and register Dani potters' association to enable their products exhibited on Ghana Tourism Authorityonlineportal - Single Window Destination. This would lead to the promotion of Dani pottery products at the local, regional, national and international levels whereby such products could be viewed and purchased online across the globe with the monies paid directly to the members. (Ghana Tourism Authority -RM, personal communication, July 7, 2021)

Per the accounts of the Upper West Regional Manager of Ghana Tourism Authority, itimplies that a reconnaissance survey of the traditional pottery products of Dani by officials of GTA and positive outcome of the survey would necessitate further actions for the development of an attractive pottery related tourism destination in Dayi.

\section{Conclusions and Recommendations}

The study examined the cultural tourism potentials of Dani traditional pottery art and concludes that the traditional pottery art in Dani is an inherited indigenous handicraft of the ancient women of the community which has since been preserved and perpetuated by the contemporary generation of the community. The study found that the pottery receptacles of Dani are repositories of indigenous cultural heritage, artistry, philosophy, knowledge and skills of Dayi people. Besides, the indigenous decorative designs and the premises of the deployment of pottery receptacles in Dayi are underpinned by the sociocultural, socioreligious, sociopolitical and socioeconomic lifelines of the people of Dani positing sufficient grounds and the need for the development and promotion of Dani traditional pottery art into an attractive cultural tourism destination for global patronage.

On the need for Dani Traditional Pottery Art to be developed into an attractive cultural tourism destination, there was unanimity in the accounts rendered by key stakeholder-respondents. It was established that the Upper West regional management of Ghana Tourism Authority was ready to initiate a reconnaissance survey of the community to enable it to come up with appropriate interventions that could lead to the formation and registration of Dani potters into an active association. This would pave way for the promotion of Dani traditional pottery products on the Ghana Tourism Authority'sonlineportal known as Single Window Destination for such products to be viewed online and purchased across the globe with the monies paid directly to the potters. Therefore, it is recommended that the stakeholders involved (the Chief, Queen Mother and Elders of Dayi; the Assembly Member in charge of Dayi; the Municipal Chief Executive of Sissala East Municipal Assembly, Sissala East Municipal Director of Centre for National Culture, and the Regional Manager of Ghana Tourism Authority) should collaborate to ensure a quick reconnaissance survey of Dani traditional pottery art is initiated by the regional management of Ghana Tourism Authority to come up with the appropriate interventions for the development of Dayi traditional pottery art into an attractive cultural tourism destination and the promotion of same on 
GTA Single Window Destination online portal for the associated sociocultural and economic benefits of the art to the potters, Sissala East Municipality and Ghana by extension.

\section{References}

i. Al-Ababneh, M. \&Masadeh, M. (2019). Creative cultural tourism as a new model for cultural tourism. Journal of Tourism Management Research,6(2), 109-118.

ii. Asante, E. A.,Adjei, K. \&Opoku-Asare, N. A. (2013). The theoretical and socio-cultural dimensions of Kpando women's pottery. Research on Humanities and Social Sciences, 3(1), 60-72.

iii. Asmah, A. E., Mate, M. M. \&Daitey, S. T. (2016). Tourist art: A prime phase of Sirigu art. European Journal of Research in Social Sciences, 4(2), 1-14.

iv. Bhatta, C. (2016). The role of arts in promoting tourism: A case of tourism development in Thamel area. Journal of Advanced Academic Research (JAAR), 3(1), 177-184.

v. Google Map. (2021). Retrieved on July, 12 from: https://www.google.com/maps/@10.8479266,-2.0325208,13z?hl=en

vi. Navei, N. (2020). Sociocultural contexts of Chaira pottery art. Journal of African Art Education,1(1), 1-18.

vii. Ngozi, E. \&Chinonso, I. (2016). The role of cultural resources in tourism development in Awka. African Journal of Hospitality, Tourism and Leisure, 5(2), 1-12.

viii. Pratt, C. \&Tarlow, P. (2014). The cultural tourism product, meeting of cultures: Safety, security and planning guidelines. International Journal of Safety and Security in Tourism and Hospitality 1(8), 29-45.

ix. Sandelowski, M. (2000). Focus on research methods: Whatever happened to qualitative description? Research in Nursing \& Health, 23, 334-340.

x. Segbefia, A.Y. (2009). A study on handicrafts as a pro-poor tourism development strategy in four craft villages in Ashanti region, Ghana (Doctor of Philosophy). University of Ghana, Legon.

xi. Şengün, G. (2011). Cultural tourism in tourism industry supervisor (Project Work). Atilim University.

xii. Sheldon, B. (2016). Indigenous expertise: African women's artistry connecting across time and space. Africa Review, 9(1) 13-27.

xiii. Sirika, B. (2008). Socio-economic Status of Handicraft Women amongMacca Oromo of West Wallaga, Southwest Ethiopia. Ethiop. J. Educ. \& Sc., 4(1), 1-15.

xiv. Tegegn, E., Amsalu, D. \&Tefera, T. (2020) Cultural Tourism Potentials of the Dorzé Village, Southern Ethiopia. Journal Tourism Hospital, 9(5:438), 1-7.

xv. Vučetić, A. (2011). New concept of cultural tourism management in Montenegro. Selective Tourism, 6, 5-23.

xvi. Wemegah, R. (2009). Architecture, mural decoration and pottery in Sirigu culture (Master of Arts Thesis). Department of General Art Studies: Kwame Nkrumah University of Science and Technology.

xvii. Wemegah, R. (2014). Pottery in Sirigu society: The socio-cultural relevance and the need for sustenance. International Journal of Innovative Research \& Development, 7(3), 87-94.

xviii. Yussif, I. \&Adu-Gyamfi, V. E. (2017). Concepts of some indigenous pottery decorative techniques inNorthern Ghana. European Scientific Journal,13(32), 77-88.

xix. Yussif, I., Adu-Gyamfi, V. E. \&Tabi-Agyei, E. (2018). Documentation of some identified traditional pottery decorative techniques in Northern Ghana. ARJASS, 6(3), 1-11.

xx. Zargham, H. (2007). Sustainable tourism development and handicrafts in the developing world. WIT Transactions on Ecology and the Environment, 102, 1011- 1017.

xxi. Zhang, Y. (2011). Cultural Tourism products: A case study in the Xi'an City. UNLV Theses, Dissertations, Professional Papers, and Capstones, 1077, 1-36. 